\title{
Menumbuhkan Sikap Tenggang Rasa antar Siswa dalam Pembelajaran Melalui Metode AI (Apreciative Inquiry)
}

\author{
Agustina Iriyanti ${ }^{*}$, Syahdan Arsyayudha Nusabelani2), Devi Erlina ${ }^{3)}$, \\ Lina Agustina ${ }^{4)}$ \\ 1,2,3,4)Universitas Muhammadiyah Surakarta \\ *)A710170029@student.ums.ac.id
}

\begin{abstract}
Abstrak: Penelitian ini bertujuan untuk menumbuhkan sikap tenggang rasa antar siswa di sekolah terutama di dalam kelas, menumbuhkan sikap percaya diri, saling melindungi, dan saling percaya, kemudian menumbuhkan sikap berani dan berpikir positif dalam berbagai keadaan, melalui metode Problem Solving AI (Appreciative Inquiry). Penelitian ini merupakan penelitian kualititatif dekriptif yang akan memberikan gambaran tentang proses pembelajaran di kelas dimana guru akan menyampaikan suatu materi dan siswa diminta untuk membahas materi secara berkelompok, melalui metode berkelompok, akan terlihat siswa yang memiliki sikap tenggang rasa atau tidak, memiliki rasa percaya diri atau pemalu, memiliki sikap peduli ataupun individualis serta siswa apakah membedakan siswa yang satu dengan lainnya menurut kemampuannya. Penelitian ini juga menganalisa siswa dalam proses pembelajaran aktif, apakah mereka antusias atau justru merasa bosan dan terbebani. Subjek penelitian adalah siswa kelas X Multimedia 1 di SMK Negeri 6 Sukoharjo dengan jumlah 34 siswa. Metode pengumpulan data dengan observasi dan wawancara. Hasil penelitian akan menunjukkan hambatan - hambatan dalam pembelajaran kurangnya rasa tenggang rasa antar siswa, kurang pahamnya beberapa siswa mengenai materi yang dibahas, kurangnya sikap percaya diri.
\end{abstract}

Kata kunci : Appreciative Inquiry, Tenggang rasa

\section{PENDAHULUAN}

Appreciative inquiry (AI) adalah salah satu intervensi yang telah digunakan sebelumnya untuk meningkatkan psikologi positif dalam studi organisasi yang terbaik (Bushe, 2007). AI adalah metodologi penelitian tindakan yang menggunakan pertanyaan untuk mendorong refleksi keberhasilan masa lalu sebagai cara untuk menciptakan solusi baru. Pada intinya, AI adalah proses yang membantu individu untuk membangun wacana berdasarkan positif dan kemungkinan masa depan (Moody, Horton-Deutsch, \& Pesut, 2007)

Ketika AI diimplementasikan, biasanya dimulai dengan kumpulan cerita positif yang menangkap organisasi dan orang-orang di terbaiknya Sementara beberapa praktisi berhenti dengan langkah ini, yang lain memanfaatkan informasi ini untuk membuat rencana dan proses yang mendorong dan memelihara tindakan improvisasi oleh anggota sistem. Langkah ini biasanya melibatkan diskusi yang difasilitasi untuk memperkuat ide-ide baru berdasarkan pengalaman positif masa lalu (Bushe \& Kassam, 2005).

AI memiliki kapasitas untuk memperluas apa yang diketahui tentang dampak kepositifan dengan memberi seseorang keberanian 
berdasarkan kekuatannya. AI dapat menyebabkan perubahan yang berarti dalam pendidikan (misalnya, persepsi praktik berbagi informasi yang lebih menguntungkan; inisiatif peningkatan proses yang didukung secara luas, seperti perubahan proses), dan juga penyelidikan berdasarkan kekuatan dapat memengaruhi kesiapan seseorang untuk berubah dan mengatasi reaksi awal, seringkali negatif terhadap perubahan yang akan datang (Bushe \& Kassam, 2005)..

Pengaplikasian AI ini dapat selaras jika disatukan oleh rasa tenggang rasa. Tenggang rasa merupakan sikap seseorang yang mampu menghargai dan menghormati orang lain baik secara lisan maupun perbuatan. (Akhmad, 2012:72) menyatakan bahwa tenggang rasa adalah suatu sikap hidup dalam ucapan, perbuatan, dan tingkah laku yang mencerminkan sikap menghargai dan menghormati orang lain. Artinya tenggang rasa merupakan sikap yang mencerminkan menghargai dan menghormati orang lain melalui ucapan, perbuatan, dan tinggah laku.

Dewi (2012) sikap tenggang rasa adalah suatu sikap hidup dalam ucapan, perbuatan, dan tingkah laku yang mencerminkan sikap menghargai dan menghormati orang lain. Artinya tenggang rasa merupakan sikap yang menghormati dan menghargai orang lain melalui ucapan, perbuatan, dan tingkah laku. Senada dengan Alpian (2016) bahwa tenggang rasa atau tepa selira adalah sikap seseorang yang menempatkan perasaannya pada perasaan orang lain. Konsep tenggang rasa identik dengan konsep mencintai, menghargai sesama manusia.

Ada beberapa indikator seseorang dikatakan memiliki sikap tenggang rasa. Ahmadi (2000:34) menyatakan bahwa sikap tenggang rasa dapat dilihat dari : 1) adanya saling menghargai satu sama lain;2) menghindari sikap masa bodoh; 3) tidak menggangu orang lain; 4) selalu menjaga perasaan orang lain; 5) dalam bertutur kata tidak menyinggung perasaan orang lain; 6) selalu menjaga perasaan orang lain dalam pergaulan.

Akhmad (2012:75) menyatakan bahwa unsur unsur tenggang rasa terdiri dari atas (1) menghormati hak-hak orang lain; (2) memiliki rasa sayang terhadap orang lain; (3) menjaga sikap, perkataan dan tingkah laku yang dapat membuat orang lain tersinggung. Suryana (2011:134) juga memaparkan bahwa unsur-unsur tenggang rasa meliputi (a) menghormati orang lain; (b) kerelaan membantu teman yang mengalami musibah; (c) kemauan mengendalikan sikap, perbuatan, dan tutur kata yang dapat menyinggung atau melukai perasaan.orang lain.

Penelitian metode untuk menumbuhkan sikap tenggang rasa telah banyak dilakukan. Seperti Salim (2010) menemukan perbedaan yang sangat signifikan antara penerapan model konsiderasi dan metode tradisional terhadap sikap tenggang rasa siswa SMA. Dengan menggunakan model pembelajaran konsiderasi sikap tenggang rasa siswa jauh lebih meningkat daripada metode tradisonal.

Dalam penelitian ini untuk menciptakan rasa tenggang rasa dibutuhkan suatu metode untuk mendekatkan semua elemen yaitu metode AI. Dengan simulasi dalam suatu pembelajaran kita dapat melakukan semuanya. Siswa dan Guru dapat saling bekerjasama dalam suatu kelas dan menghasilkan perubahan sikap melalui metode tersebut. 
Tujuan artikel ini adalah untuk mendeskripsikan sikap tenggang rasa antar siswa di sekolah terutama di dalam kelas, menumbuhkan sikap percaya diri, saling melindungi, dan saling percaya, kemudian menumbuhkan sikap berani dan berpikir positif dalam berbagai keadaan dengan menggunakan metode AI (Appreciative Inquiry) di SMK Negeri 6 Sukoharjo.

\section{METODE PENELITIAN}

Penelitian ini menggunakan rancangan deskriptif kualitatif. Menurut Ibrahim (2015: 59) penelitian deskriptif adalah penelitian yang dimaksudkan untuk melukiskan, menggambarkan, atau memaparkan keadaan objek yang diteliti sebagaimana adanya, sesuai dengan situasi dan kondisi ketika penelitian tersebut dilakukan. Meleong dalam Herdiansyah (2010: 9) mendefinisikan bahwa penelitian kualitatif adalah suatu penelitian ilmiah, yang bertujuan untuk memahami suatu fenomena dalam konteks sosial secara alamiah dengan mengedepankan proses interaksi komunikasi yang mendalam antara peneliti dengan fenomena yang diteliti. Subjek penelitian yaitu 34 siswa kelas X Multimedia 1 SMK Negeri 6 Sukoharjo, terdiri dari 17 siswa laki-laki dan 17 siswa perempuan dengan tingkat kemampuan yang heterogen. Penelitian dilakukan dalam satu kali pertemuan berupa pembelajaran biasa guru memberikan materi pembelajaran kemudian siswa diminta untuk bekerja kelompok untuk membahas materi tersebut, kemudian siswa diminta untuk presentasi dan tanya jawab. Setelah proses tersebut kemudian siswa diminta untuk mengisi lembar evaluasi observasi dan sesi wawancara tidak terstruktur kepada beberapa siswa.

\section{HASIL DAN PEMBAHASAN}

\section{Hasil Observasi Kelas}

Penyampaian materi

Pada fase ini murid hanya bertugas mendengarkan dan guru menerangkan materi seperti biasanya namun hanya menyampaikan sekilas, guru juga memberikan kesempatan kepada murid untuk bertanya, pada fase ini murid - murid rata - rata kurang tertarik dan cenderung mencari kesibukan sendiri seperti bermain HP, berbicara dengan temannya, atau tidur. Sebagian kecil siswa ada yang memiliki perhatian yang lebih terhadap materi yang disampaikan akan lebih antusias dan ada beberapa pertanyaan yang ditanyakan. Guru hanya akan memancing murid untuk bertanya karena pada fase ini guru tidak meerangkan keseluruhan materi yang ada.

1) Pembentukan Tugas Kelompok

Guru akan memberikan beberapa sub materi yang akan dibahas oleh murid secara berkelompok, kebetulan dalam kelas X MM1 ada 32 siswa yang hadir maka dibagi menjadi 8 kelompok dengan 1 kelompok terdiri dari 4 murid. Penentuan anggota kelompok dibebaskan untuk 
melihat sikap kepedulian dan sikap toleransi di kelas tersebut. Siswa di kelas cenderung mencari sisi praktis yaitu dengan menarik teman yang berada di depan atau di belakang bangku mereka tanpa memilih2 teman. Namun ada 1 murid yang tidak bergerak mencari kelompok dan teman sebangku dengannya tidak merespon untuk mengajak untuk kelompok dengannya, dan akhirnya dia berada di kelompok lain karena terpaksa kekurangan anggota. Dari sini dapat terlihat siswa yang bersangkutan yang tidak memiliki kepercayaan diri tinggi dan tidak memiliki inisiatif untuk bergabung akan cenderung tidak diperhatikan oleh teman - teman disekitarnya.

2) Proses pembelajaran berkelompok

Dalam fase ini siswa diminta berdiskusi dengan sub bab yang sebelumnya sudah dibagi per kelompoknya, disini juga guru meminta 1 orang menjadi ketua kelompok untuk memimpin kelompok tersebut. Dari 8 kelompok hanya ada 2 kelompok yang ketuanya dapat mengkoordianasi anggota kelompoknya untuk berdiskusi karena ketua kelompok tersebut ternyata aktif di organisasi disekolah dan memiliki kepercayaan diri yang tinggi, sedangkan 6 kelompok lainnya hanya asal memilih dari siswa yang pintar saja dan proses diskusi di kelompok tersebut tidak efektif karena hanya sebagian yang mampu berdiskusi sedangkan yang lainnya mencari kesibukan sendiri, dari sini dapat dilihat pemilihan siswa yang memiliki jiwa kepemimpinan dan bertanggung jawab serta mampu berbaur dengan teman - teamnnya dapat berpengaruh postif terhadap siswa lain karena dapat menyampaikan pendapatnya dan merasa dapat diandalkan dikelompok tersebut, sedangkan sedangkan siswa yang memiliki prestasi baik namun tidak memiliki sikap kepemimpinan, tanggung jawab dan kepedulian akan mengerjakan sesuatunya sendiri dan anggota lainnya akan bersikap pasif dan menyerahkan segalanya pada satu orang saja. Penyampaian materi secara kelompok dapat berjalan baik dan mudah dipahami oleh siswa apabila ketua kelompok dapat mengkoordinasi dengan baik. Tidak harus yang pandai namun seseorang yang memiliki jiwa kepemimpinan yang tinggi.

3) Presentasi Antar Kelompok

Dalam presentasi ini guru memberikan kebebasan kepada murid untuk menunjuk siapa saja yang mau maju kedepan dan presentasi tidak harus ketua kelompok. Namun rata - rata murid akan memilih ketua kelompoknya ke delapan kelompok menunjuk ketua kelompoknya untuk maju presentasi. Presentasi yang disampaikan memiliki perbedaan ada yang menyampaikan keseluruhan apa yang ada di sub materi yang dibahas ada juga yang menyampaikan intinya saja. Lalu ada sesi tanya jawab, kelompok yang maju didepan memberikan pertanyaan kepada anggota kelompok lain, ini untuk menngecek apakah siswa yang berada di tempat duduk dapat memahami apa yang sudah di presentasikan. Guru memberikan kebebasan siswa siapa yang akan memberikan pertanyaan dan siapa yang akan menjawab, rata - rata siswa hanya akan memilih ketuanya 
untuk menanyakan pertanyaan, namun saat menjawab pertanyaan siswa banyak yang ingin menjawab pertanyaan tersebut. Disini kita dapat mengetahui sampai mana siswa memahami materi yang disampaikan serta menumbuhkan sikap percaya diri pada siswa, saling membantu satu sama lain.

4) Evaluasi

Tahap terakhir yaitu mengevaluasi keseluruhan proses belajar, guru menyimpulkan apa yang sudah di diskusikan, siswa diberikan post test dan disini guru dapat mengetahui sampai dimana proses pemahaman siswa terhadapat sutau pembelajaran dan guru dapat melihat sikap tenggang rasa diantara siswa tersebut, apakah siswa saling peduli, apakah siswa antusias, sikap percaya diri dan kemampuan memanage diri dapat terlihat dalam proses ini.

\section{Hasil Wawancara}

Setelah mengadakan evaluasi di dapat 6 siswa perwakilan dari kelas untuk menjadi sample 1 siswa berprestasi dan aktif, 3 siswa kurang berprestasi dan pasif, 1 siswa berprestasi dan pasif, 1 siswa kurang berprestasi dan pasif.

5) Sikap Tenggang rasa

Ada 3 indikator dalam menilai sikap tenggang rasa yaitu toleransi, Kepedulian, dan pengendalian diri.

Pada toleransi dari ke 6 siswa yang diwawancarai semuanya memiliki sikap toleransi yang bagus baik toleransi terhadap umat berbeda agama, berbeda suku, dll.

Pada Kepedulian ada 4 siswa memiliki sikap kepedulian yang standart dan 2 lainnya tidak terlalu. Siswa yang cenderung memilki prestasi yang bagus akan lebih mementingkan dirinya untuk mencapai sesuatu, kurangnya kepedulian terhadapa teman - temannya dan juga pendapat temannya. Sedangkan siswa yang memiliki kemampuan biasa - biasa saja memiliki sikap kepedulian yang baik.

Pada Pengendalian diri siswa yang beprestasi lebih bisa mengendalikan dirinya seperti bersikap dan berprilaku, mereka cenderung menata apa yang akan dia lakukan, sedangkan lainnya hanya sekedar berjalan sesuai dengan keinginannya tanpa memikirkan lainnya.

Indikator tenggang rasa dalam penelitian ini senada dengan temuan Suhendri (2017) yang menemukan instrumen pengukuran tenggang rasa yang dapat dikembangkan menjadi 3 dimensi, yaitu: (a) toleransi, indikatornya : (i) menghormati dan menghargai hak-hak orang lain; (b) peduli, indikatornya : (i) memiliki kepedulian terhadap orang lain dan lingkungan, (ii) membantu orang lain yang terkena musibah atau kemalangan; (c) pengendalian diri, indikatornya : (i) mengendalikan ucapan, sikap, dan tingkah laku, (ii) menerima kelebihan dan kekurangan orang lain.

6) Proses Apreciative Inquiry

Ada 4 proses yang dilalui dalam AI tersebut yaitu 
Discover/Menemukan,

Dream/Mimpi,

Design/Merancang,

Destiny/Mewujudkan.

- Discover/Menemukan

Pada tahap ini siswa memiliki passion yang dia milki, prestasi apa yang akan berdampak postif terhadap dirinya, sebagian siswa telah menemukan passion dalam dirinya dan memiliki beberapa prestasi yang dia raih. Tinggal bagaimana mengembangkannya. Sebagian siswa belum mengetahui apa yang jadi keunggulan pada dirinya, butuhnya sikap membangun dari guru pada murid untuk menemukan passion dari masing - masing siswa.

\section{- DreamMimpi}

Setelah mengetahui passion yang ada pada dirinya siswa akan memikirkan atau bermimpi akan seperti apa dia kedepannya, siswa yang belum mengetahui passionnya akan sulit bermimpi akan seperti apa dia kedepannya atau mimpi yang dia impikan jauh dari apa yang ia lakukan sekarang. Butuhnya rasa percaya diri dalam merancang mimpi tersebut.

\section{- Design/Merancang}

Setelah mengetahui kedapannya apa yang ia inginkan, siswa akan mulia merancang jalan seoerti apa yang akan mewujudkan mimpinya seperti belajar, berusaha, berdoa dan sebagainya, seluruh siswa sudah dapat mencoba berusaha dalam merancang amsa depannya walaupun ada sebagian yang masih belum memahami apa yang akan ia raih kedepannya.

\section{- Destiny/Kenyataan}

Setelah melalui semua proses siswa yang sudah memikirkan segalanya dengan matang akan mewujudkan apa yang sudah diimpikannya, ataupun jika tidak sesuai dengan apa yang ia impikan akan ada rasa puas dan bangga terhadap dirinya stelah melalui proses usaha yang sudah dilaluinya, jika siswa kesulitand alam mewujudkan mimpinya guru dapat membimbing siswa dalam mengembangkan bakat dibantu orang tua mendukung apa yang diinginkan anaknnya.

\section{SIMPULAN}

Antara sikap tenggang rasa dan metode pencapaian suatu tujuan menggunakan metode AI saling berhubungan, jika siswa memiliki sikap tenggang rasa siswa akan lebih optimis dan percaya diri dalam menentukan masa depan dan juga pembelajaran akan cenderung kondusif karena siswa memiliki tujuan yang pasti kedepannya, di dukung sikap saling peduli dan sikap membangun akan membuat siswa lebih dapat memanage diri sendiri tanpa ada rasa minder dengan apa yang ia inginkan, dukungan dari segala aspek memberikan dampak positif terhadap minat belajar siswa. Memberikan kesan positif terhadap siswa yang kurang memiliki prestasi dan bermasalah kan membuat dirinya lebih percaya diri. Sikap tenggang rasa akan muncul jika sikap postif sudah dibangun sejak dini di dalam diri siswa. 


\section{DAFTAR PUSTAKA}

Alpian, Yayan. 2016. "Hubungan Pengetahuan Sila Kemanusian dengan Sikap Tenggang Rasa Pada Siswa Sdn Cibarusah Jaya 01 Kecamatan Cibarusah Kabupaten Bekasi (Studi Korelasional pada Siswa Kelas V SD)". Civics, 1 (1):73-80. ISSN 2527-9742.

Bushe, G. 2007. "Appreciative Inquiry is not (just) about the positive". OD Practitioner, No. 39, Page : 30-35.

Moody, R., Horton-Deutsch, S., \& Pesut, D. 2007. "Appreciative in-quiry for leading complex systems: Supporting the transformation of academic nursing culture". Journal of Nursing Education, No.46, Page .1-6.

Bushe, G. R., \& Kassam, A. F. 2005. "When is appreciative inquiry transformational? A meta-case analysis". Journal of Applied Behav-ioral Science, No.41,Page :161-181.

Ahmadi, A. 2000. Psikologi Sosial. Jakarta : Rineka Cipta.

Akhmad, H. 2012. "Impementasi Pendidikan Multikultural dalam Praksis Pendidikan di Indonesia". Jurnal Pembangunan Pendidikan, Vol 1. No1.Hal : 72 .

Ibrahim. 2015. MetodologiPenelitianKualitatif. Bandung: Alfabeta.

Herdiansyah, Haris. 2010. Metode Penelitian Kualitatif untuk Ilmuilmu Sosial. Jakarta: Salemba Humanika.

Dewi, K. 2012. Pendidikan Pancasila (Mengembangkan Sikap Tenggang Rasa).

Dalam

http://anythingbutordinarytoo.blogspot.com/2012/03/pendidik an pancasilamengembangkan.html. Diunduh tanggal 07-022019

Salim, Nur. 2010. "Pengaruh Penerapan Model Pembelajaran Konsiderasi Terhadap Sikap Tenggang Rasa". Jurnal Efektor, 16 (1):49-56.

Suhendri, Huri. 2017. "Pengembangan Instrumen Pengukuran Tenggang Rasa Peserta Didik". Proseding Seminar Nasional Pendidikan PGRI. Jakarta: LPPM Unindra.

Suryana, Toto. 2011. “Konsep dan Aktualisasi Kerukunan”. Jurnal Pendidikan Agama Islam, 9 (2): 127-136. 